OPEN ACCESS

Edited by:

Luke Gatiboni,

North Carolina State University,

United States

Reviewed by:

Tadeu Luis Tiecher,

Instituto Federal Farroupilha, Brazil

Djalma Eugênio Schmitt,

Federal University of Santa Catarina,

Brazil

*Correspondence:

T. Q. Zhang

Tiequan.Zhang@canada.Ca

Specialty section:

This article was submitted to

Soil Processes,

a section of the journal

Frontiers in Earth Science

Received: 12 January 2020

Accepted: 07 May 2020

Published: 23 June 2020

Citation:

Zhang TQ, Zheng ZM, Drury CF,

Hu QC and Tan CS (2020) Legacy

Phosphorus After 45 Years With

Consistent Cropping Systems

and Fertilization Compared to Native

Soils. Front. Earth Sci. 8:183.

doi: 10.3389/feart.2020.00183

\section{Legacy Phosphorus After 45 Years With Consistent Cropping Systems and Fertilization Compared to Native Soils}

\author{
T. Q. Zhang ${ }^{1 *}$, Z. M. Zheng ${ }^{2}$, Craig F. Drury', Q. C. $H u^{1}$ and C. S. Tan ${ }^{1}$ \\ ${ }^{1}$ Harrow Research and Development Centre, Agriculture and Agri-Food Canada, Harrow, ON, Canada, ${ }^{2}$ Ottawa Research \\ and Development Centre, Agriculture and Agri-Food Canada, Ottawa, ON, Canada
}

Agricultural practices affect the status of legacy phosphorus $(P)$ in soils and consequently the $\mathrm{P}$ bioavailability and susceptibility of losses to water resources. Previous studies have primarily assessed $\mathrm{P}$ status within agroecosystems, and rarely have these results been compared to native conditions. We evaluated the effects of long-term (45 years) consistent cropping [continuous corn (CC), corn-oats-alfalfa-alfalfa rotation (CR), and continuous bluegrass sod (CB)] with and without $P$ fertilization on changes in $\mathrm{P}$ fractions of different bioavailability in a Brookston clay loam, as compared to an adjacent forest native soil. Soil $P$ was separated into various inorganic $P\left(P_{i}\right)$ and organic $P\left(P_{0}\right)$ fractions using a modified sequential fractionation method. Phosphorus in native soil was predominated by moderately labile $\mathrm{P}_{\mathrm{o}}\left(\mathrm{NaOH}-\mathrm{P}_{\mathrm{o}}\right), 44 \%$, followed by moderately stable $\mathrm{P}_{\mathrm{i}}(\mathrm{HCl}-\mathrm{P}), 26 \%$. Compared to the native soil, consistent cropping without $\mathrm{P}$ fertilization significantly decreased all $\mathrm{P}$ fractions except for water-extractable $\mathrm{P}_{\mathrm{o}}$, with the largest decrease in labile $\mathrm{P}_{\mathrm{i}}$ (water- $\mathrm{P}_{\mathrm{i}}+\mathrm{NaHCO}_{3}-\mathrm{P}_{\mathrm{i}}$ ) and moderately labile $P_{\circ}$ of 65 and $73 \mathrm{mg} \mathrm{kg}^{-1}$, respectively, over 45 years. Consistent cropping with fertilization retained comparable amount of total $\mathrm{P}$ in $\mathrm{CC}$ and $\mathrm{RC}$, but increased total $\mathrm{P}$ in $\mathrm{CB}$, relative to the native soil. Averaged over cropping systems, labile $\mathrm{P}_{\mathrm{i}}, \mathrm{NaOH}-\mathrm{P}_{\mathrm{i}}$, and $\mathrm{HCl}-\mathrm{P}$ increased by 129,74 , and $20 \mathrm{mg} \mathrm{kg}^{-1}$, respectively, whereas labile $\mathrm{P}_{\mathrm{o}}$ and moderately labile $P_{0}$ decreased by 8 and $60 \mathrm{mg} \mathrm{kg}^{-1}$, respectively, compared to the native soil. This study indicates that long-term cropping significantly enhanced the rate of moderately labile $P_{0}$ mineralization, irrespective of fertilization. The increases of total $P$ and $P_{0}$ in the fertilized $C B$ plots suggest that $P$ accumulation in long-term grass fields is a concern as far as potential $P$ contamination in surface waters.

Keywords: long-term fertilization, cropping system, grass land, phosphorus fraction, inorganic phosphorus, organic phosphorus, forest ecosystem, native soil

Abbreviations: CC, continuous corn; $\mathrm{CB}$, continuous bluegrass sod; $\mathrm{CR}$, corn-oats-alfalfa-alfalfa rotation; P, phosphorus; $\mathrm{P}_{\mathrm{i}}$, inorganic $\mathrm{P} ; \mathrm{P}_{\mathrm{o}}$, organic $\mathrm{P}$. 


\section{INTRODUCTION}

Soil $\mathrm{P}$ status plays important roles in $\mathrm{P}$ bioavailability and mobility from soil to water (Simard et al., 1995; Zheng and Zhang, 2012). Phosphorus accumulates in soil when applied in excess of crop removal (Zhang et al., 2004; Hao et al., 2018). However, $\mathrm{P}$ decline in soils under agricultural production has also been observed after long-term cessation of fertilization relative to native soils due to $\mathrm{P}$ removal in the harvested crops. Hedley et al. (1982) found that total P in three grassland soil associations of the Canadian prairies after 60 to 70 years of cultivation was 12 to $29 \%$ lower than that of the adjacent permanent pastures. For two of the three soil associations, essentially all $\mathrm{P}$ losses were accounted for by $\mathrm{P}_{\mathrm{O}}$. Bowman et al. (1990) reported that half of total $\mathrm{P}$ decline was stemmed from the decrease in $\mathrm{P}_{\mathrm{o}}$ pool. Tiessen et al. (1982) considered that soil P was primarily lost from $\mathrm{P}_{\mathrm{o}}$ fraction until this fraction depleted sufficiently to allow dissolution of apatite to occur. A significant relationship between $P$ reduction and soil organic matter loss was observed by Tiessen et al. (1983). The supply of plant availability $\mathrm{P}$ was regulated by the rate of mineralization of $\mathrm{P}_{\mathrm{o}}$ (Cole et al., 1977). Those studies, as well as the ones reported recently (e.g., Tiecher et al., 2018), indicated that the mineralization of $\mathrm{P}_{\mathrm{O}}$ in cultivated soil plays important roles in both plant available $\mathrm{P}$ and $\mathrm{P}$ transformation in soil. Hedley et al. (1982) considered that P loss from cultivated soil resulted mainly from crop removal, which would account for the $75 \%$ of the decrease in total P loss from soil.

Cropping systems have large impacts on soil $\mathrm{P}$ status. Bowman and Halvorson (1997) reported P availability increased significantly in the 0 - to $5-\mathrm{cm}$ depth with continuous wheat compared with wheat fallow in central great plain of the United States, and they attributed this increase to the high return of crop residues. Zheng et al. (2003) reported larger pools of labile inorganic $\mathrm{P}(\mathrm{Pi})$ and organic $\mathrm{P}(\mathrm{Po})$ extractable with $\mathrm{NaHCO}_{3}(\mathrm{pH} 8.5)$ and moderately labile Po extractable with $\mathrm{NaOH}(0.1 \mathrm{M})$ in 30 - to $60-\mathrm{cm}$ soil in a barley-alfalfa-alfalfa rotation compared to monoculture barley. Great root biomass from perennial crops contributed to $\mathrm{P}$ accumulation in the soil layer. Although there have been research efforts dedicated to assess $\mathrm{P}$ transformations in soils under diverse cropping systems (Zhang and MacKenzie, 1997a,b; Saltali et al., 2007; Takeda et al., 2009; Ahmed et al., 2019), little information is available on comparison of soil $\mathrm{P}$ dynamics among cropping systems, especially using native soils as a reference.

The addition of fertilizer $\mathrm{P}$ not only supplies an essential nutrient to plants, but it also influences $\mathrm{P}$ distribution in pools of various bioavailability and loss susceptibility to water. Increases in labile $\mathrm{P}_{\mathrm{i}}$ and moderately labile $\mathrm{P}_{\mathrm{i}}$ in fertilized soils have been observed (Wagar et al., 1986; Zhang and MacKenzie, 1997a,b; Zheng et al., 2002; Zhang et al., 2004; von Sperber et al., 2017). It was reported that moderately labile $\mathrm{P}_{\mathrm{i}}$ is the primary sink of added fertilizer $\mathrm{P}$ and source of labile $\mathrm{P}_{\mathrm{i}}$ under long-term cropping practice in a Labarre silty clay (Zheng et al., 2002) and a Chicot sandy clay loam (Zhang et al., 2004). However, changes in moderately stable $\mathrm{P}_{\mathrm{i}}$ extractable with $0.1 \mathrm{M} \mathrm{HCl}$ were not consistent in $\mathrm{P}$ fertilized soils. Zhang and MacKenzie $(1997 a, b)$ reported moderately stable P remained constant in a
Chicot sandy clay loam over the short term, whereas Mckenzie et al. (1992), Richards et al. (1995), and Crews and Brookes (2014) found moderately stable P increased along with addition of fertilizer $\mathrm{P}$ in the long-term up to 100 years. Total $\mathrm{P}_{\mathrm{O}}$ in the fertilized soil remained unchanged (Zhang and MacKenzie, 1997b) for short-term cultivation. On the other hand, Agbenin and Goladi (1998) found the fractions of $\mathrm{P}_{\mathrm{O}}$ and residual $\mathrm{P}$, predominated by $\mathrm{Po}$, decreased in the $\mathrm{P}$ fertilized soil. The change in $\mathrm{P}_{\mathrm{o}}$ pools depends on the rate of mineralization (Tiecher et al., 2018), which is governed by complex mineralogical, chemical, and biological processes. A path analysis indicated that the role of $\mathrm{P}_{\mathrm{o}}$ pools was more important than $\mathrm{P}_{\mathrm{i}}$ pools for soil $\mathrm{P}$ transformation, and labile $\mathrm{P}_{\mathrm{o}}$ acted as a transitory pool rather than as a sink or source of $\mathrm{P}$ in a Labarre silty clay (Zheng et al., 2002) and in a very clayey Oxisol under non-tillage (Tiecher et al., 2018). Soil P dynamics in fertilized soils can be form-interactive and temporally cumulative. There is information shortage on the long-term effect of fertilizer $\mathrm{P}$ addition on soil $\mathrm{P}$, which impairs management practices being developed in a crop production that is profitable and at the same time in an environmentalfriendly manner. The objective of this study was to assess the $\mathrm{P}$ status and $\mathrm{P}$ transformation in a Brookston clay loam after 45 years of contrasting (monoculture corn vs. crop rotations) cropping systems with and without $\mathrm{P}$ fertilization, relative to the native forest soil.

\section{MATERIALS AND METHODS}

\section{Experiment Design and Plot Management}

An experiment was initiated in 1959 at Eugene Whelan Research farm, Woodslee, Ontario, Canada $\left(42^{\circ} 13^{\prime} \mathrm{N}\right.$ latitude, $82^{\circ} 44^{\prime} \mathrm{W}$ longitude). The mean annual air temperature is $8.7^{\circ} \mathrm{C}$, and the mean annual precipitation is $876 \mathrm{~mm}$. The soil was classified as Brookston clay loam (Typic Argiaquoll), consisting of $28 \%$ sand, 35\% silt, 37\% clay, $619 \mathrm{mg} \mathrm{kg}^{-1} \mathrm{Al}$ (Mehlich-3 extractable), $310 \mathrm{mg} \mathrm{kg}^{-1} \mathrm{Fe}$ (Mehlich-3 extractable) (Wang et al., 2012), and $2.3 \%$ organic carbon in the Ap horizon.

Treatments consisted of combinations of three cropping systems and two regimes of fertilization. Cropping systems included conventionally tilled continuous corn (Zea mays L., CC), corn-oats (Avena sativa L.)-1st alfalfa (Medicago sativa L.)2nd alfalfa rotation (CR), and continuous Kentucky bluegrass sod (Poa pratensis L., CB). Each phase of the corn-oats-alfalfaalfalfa rotation was presented in each year. However, only the corn phase of the rotation, $\mathrm{CC}$ and $\mathrm{CB}$, was selected for this study. The plot size was $76.2 \times 12.2 \mathrm{~m}$ each. Conventional tillage consisted of a moldboard plowing to $0.18-\mathrm{m}$ depth in the fall and a disking and harrowing in the spring just prior to planting. Conventional tillage was conducted every year for CC plots and in 2 of 4 years for the rotation treatments (i.e., following the second year alfalfa and following the rotation corn harvest). The CB plots were not tilled. Corn was planted at 55,000 seeds $\mathrm{ha}^{-1}$ with $1.0-\mathrm{m}$ row spacing. All fertilized plots received 8$32-16$, which provided $16.8 \mathrm{~kg} \mathrm{~N} \mathrm{ha}^{-1}$ as ammonium nitrate $\left(\mathrm{NH}_{4} \mathrm{NO}_{3}\right), 67.2 \mathrm{~kg} \mathrm{P}_{2} \mathrm{O}_{5} \mathrm{ha}^{-1}$ as triple superphosphate, and 
$36.2 \mathrm{~kg} \mathrm{~K}_{2} \mathrm{O} \mathrm{ha}^{-1}$ as potassium chloride $(\mathrm{KCl})$ prior to planting each year. In addition, corn also received $112 \mathrm{~kg} \mathrm{~N} \mathrm{ha}^{-1}$ of side-dressed $\mathrm{NH}_{4} \mathrm{NO}_{3}$, applied in bands $15 \mathrm{~cm}$ on either side of the row (2- to $5-\mathrm{cm}$ depth) when corn was at six-leaf stage (usually in early-mid June). Herbicides were applied at regionally recommended rates for weed control in corn and oat production.

Corn yields were measured annually by harvesting $33-\mathrm{m}$ lengths of 10 individual rows. Grain moisture content was determined on corn grain subsamples. Alfalfa was cut and baled two to three times a year and removed from the field. Cereal and forage biomasses were estimated, and plant samples collected using the sampling square technique. The plant $\mathrm{P}$ removal was the product of dry matter and $\mathrm{P}$ concentration in all harvested plant tissues. The harvest index of 0.5 for corn was used to estimate shoot biomass (Bolinder et al., 2007). The shoot-root ratios of 5 , 3,2 , and 2 were used to calculate the root and stubble biomass of corn, oats, alfalfa, and bluegrass sod, respectively (Bolinder et al., 1997, 2002). The national average $P$ concentrations were used for the harvested tissues of corn, oats, alfalfa, and sod, and $\mathrm{P}$ concentrations in root and stubble biomass were estimated as $0.5 \%$ of their concentrations in harvested plant tissues (National Research Council, 1982). The P budget after 45-year cropping practices is shown in Table 1. The soil at adjacent woodlot (native forest) was considered to be native soil. The vegetation species for the woodlot are native grasses and deciduous trees. Not only was the woodlot not fertilized, but it was also not tile drained, whereas all of the field plots were systematically tile drained.

\section{Soil Sampling and P Fractionation}

Soil samples were taken from 0 - to $20-\mathrm{cm}$ top layer in May 2003, using a 3.2-cm-diameter auger. Soil samples were air-dried, ground, and passed through a $2-\mathrm{mm}$ sieve. Soil subsamples were further ground and passed through a 100-mesh sieve.

Soil $\mathrm{P}$ was fractioned using a modified Hedley (Hedley et al., 1982) sequential extraction procedure (Zhang et al., 2004). In brief, 0.5-g soil was extractable sequentially with $30 \mathrm{~mL}$ of deionized water, $0.5 \mathrm{M} \mathrm{NaHCO}_{3}$, the first $0.1 \mathrm{M} \mathrm{NaOH}, 1.0 \mathrm{M}$ $\mathrm{HCl}$, and the second $0.1 \mathrm{M} \mathrm{NaOH}$ by shaking the suspension for $16 \mathrm{~h}$, centrifuging for $10 \mathrm{~min}$ at $16,000 \mathrm{~g}$, and passing through a $0.45-\mu \mathrm{m}$ Millipore membrane filter (mixed cellulose ester). An aliquot $(10 \mathrm{~mL})$ of the $\mathrm{NaHCO}_{3}$ and $\mathrm{NaOH}$ extractants was acidified to precipitate extractable organic matter, and the supernatant was analyzed for $\mathrm{P}_{\mathrm{i}}$. The 2 nd $\mathrm{NaOH}$ extraction used in this study enabled the extraction of $\mathrm{P}$ (either $\mathrm{P}_{\mathrm{i}}$ or $\mathrm{P}_{\mathrm{o}}$ ), which is held more strongly at internal surface of soil aggregates (Hedley et al., 1982; Zhang and MacKenzie, 1997b). Another aliquot $(10 \mathrm{~mL})$ of the deionized water, $\mathrm{NaHCO}_{3}$, and $\mathrm{NaOH}$ extracts was digested in an autoclave $\left(103.4 \mathrm{kPa}, 121^{\circ} \mathrm{C}\right.$ for $1 \mathrm{~h})$ with $10 \mathrm{~mL}$ of $9 \mathrm{M} \mathrm{H}_{2} \mathrm{SO}_{4}$ and ammonium persulfate $\left[\left(\mathrm{NH}_{4}\right)_{2} \mathrm{~S}_{2} \mathrm{O}_{8}\right](0.5 \mathrm{~g})$ and analyzed for total $\mathrm{P}\left(\mathrm{P}_{\mathrm{t}}\right)$. The difference between $\mathrm{P}_{t}$ and $\mathrm{P}_{\mathrm{i}}$ was considered as $\mathrm{P}_{\mathrm{o}}$ (Tiessen and Moir, 1993). Residual $\mathrm{P}$ in soil after sequential extraction was determined using the digestion method with concentrated $\mathrm{H}_{2} \mathrm{SO}_{4}$ and $\mathrm{H}_{2} \mathrm{O}_{2}$. Phosphorus concentrations were determined colorimetrically using a flow injection autoanalyzer (Quikchem FLA 8000 series; Lachat Instruments, Loveland, CO, United States) with the molybdate-ascorbic acid procedure (Murphy and Riley, 1962). Consequently, soil $\mathrm{P}$ was separated into water-extractable $\mathrm{Pi}$ and Po (water- $\mathrm{P}_{\mathrm{i}}$ and $\mathrm{P}_{\mathrm{o}}$ ), $\mathrm{NaHCO}_{3}$ extractable $\mathrm{P}_{\mathrm{i}}$ and $\mathrm{P}_{\mathrm{o}}\left(\mathrm{NaHCO}_{3}\right.$ $\mathrm{P}_{\mathrm{i}}$ and $-\mathrm{P}_{\mathrm{o}}$ ), $\mathrm{NaOH}$ extractable $\mathrm{P}_{\mathrm{i}}$ and $\mathrm{P}_{\mathrm{o}}$ (sum of the first and the second $\mathrm{NaOH}$ extractions), acid $\mathrm{P}$ ( $\mathrm{HCl}-\mathrm{P})$, and residue $\mathrm{P}$ (Res-P). Both water- and $\mathrm{NaHCO}_{3}-\mathrm{P}$ were considered as labile $\mathrm{P}$. The NaOH-P was considered as moderately labile P. The HCl$\mathrm{P}$ was referred as moderately stable $\mathrm{P}$. Res- $\mathrm{P}$ was considered to be stable $\mathrm{P}$. Soil $\mathrm{P}$ was expressed in $\mathrm{mg} \mathrm{P} \mathrm{kg}^{-1}$ soil. Total extractable $\mathrm{P}_{\mathrm{i}}$ or $\mathrm{P}_{\mathrm{o}}$ was the sum of $\mathrm{P}_{\mathrm{i}}$ or $\mathrm{P}_{\mathrm{o}}$ extractable by water, $\mathrm{NaHCO}_{3}, \mathrm{NaOH}$, and $\mathrm{HCl}$ reagents. Total $\mathrm{P}$ was measured directly by digesting soil subsamples with $\mathrm{H}_{2} \mathrm{SO}_{4}$ and $\mathrm{H}_{2} \mathrm{O}_{2}$, with $\mathrm{P}$ concentrations determined using the same approach as for other samples described above. The differences between the total $\mathrm{P}$ and the sum of $\mathrm{P}$ factions were within $\pm 3 \%$.

\section{Statistical Analysis}

The statistical analysis of the cropping treatments and the native soil was performed separately for the fertilized and non-fertilized plots using the least significant difference (LSD) $t$ test at a significance level of $P \leq 0.05$ (SAS Institute, 1999 Cary, NC, United States, 1999).

\section{RESULTS AND DISCUSSION}

\section{Phosphorus Budget}

The $\mathrm{P}$ budget was calculated as the difference between the cumulative fertilizer $\mathrm{P}$ inputs and the cumulative $\mathrm{P}$ removal by plants using the available data from the establishment of these plots. The P deficits were expectedly observed after 45-year consistent cropping without P fertilization in both CC and CR plots, whereas no changes were anticipated in the $\mathrm{CB}$ plots as the grasses were not removed from the plots (Table 1). However, there was a great $\mathrm{P}$ surplus in the fertilized CB plots, which was attributed to no $\mathrm{P}$ removal, as the grasses were only cut and not removed in addition to the annual inputs of fertilizer P. This treatment simulated a grass buffer strip. A slight $\mathrm{P}$ deficit was found in the fertilized CC and CR plots, suggesting an apparent $\mathrm{P}$ balance in the two corn plots after 45 years of long-term cropping with annual fertilization.

\section{Total Soil P}

Total $\mathrm{P}$ content in native soil was $667 \mathrm{mg} \mathrm{kg}^{-1}$ (Figure 1). The $\mathrm{P}_{\mathrm{o}}$ extractable with $0.1 \mathrm{M} \mathrm{NaOH}\left(\mathrm{NaOH}-1-\mathrm{P}_{\mathrm{o}}+\mathrm{NaOH}-2-\mathrm{P}_{\mathrm{o}}\right)$ was the dominant $\mathrm{P}$ fraction, accounting for $44 \%$ of total $\mathrm{P}$, followed by HCl-P 26\%. Labile $\mathrm{P}$ (water- $\mathrm{P}_{\mathrm{i}}$ and $-\mathrm{P}_{\mathrm{o}}+\mathrm{NaHCO}_{3}-$ $\mathrm{P}_{\mathrm{i}}$ and $-\mathrm{P}_{\mathrm{o}}$ ) and Res- $\mathrm{P}$ accounted for $20 \%$ and $16 \%$, respectively. The high proportion of $\mathrm{NaOH}-\mathrm{P}_{\mathrm{o}}$ may have been due to two extractions by $0.1 \mathrm{M} \mathrm{NaOH}$ in our study. The small proportion of labile $\mathrm{P}$ in our Brookston clay loam was comparable to the native forest Brown Chernozemic at 10\% labile P (Schoenau et al., 1989) and permanent Black Chernozemic pasture soil at 12\% labile P (Hedley et al., 1982). The content of HCl-P in our native Brookston clay loam was higher than those in native Gleysolic and Gray Luvisolic soils (Schoenau et al., 1989) and lower than those in Chernozemic soils (Hedley et al., 1982; 
TABLE 1 | Phosphorus budget after 45-year contrasting cropping practices in a Brookston clay loam at Woodslee, ON, Canada.

\begin{tabular}{|c|c|c|c|c|c|}
\hline Cropping system & Cumulative $\mathbf{P}$ input & Cumulative P uptake ${ }^{\dagger}$ & Cumulative $\mathbf{P}$ input in crop residuals ${ }^{\ddagger}$ & Cumulative $P$ removal & Soil P budget ${ }^{£}$ \\
\hline & $\mathrm{kg} \mathrm{P} \mathrm{ka}^{-1}$ & & & & \\
\hline & \multicolumn{5}{|c|}{ Fertilized } \\
\hline $\mathrm{CC}$ & 1,291 & $1,486 a^{£}$ & $71 \mathrm{c}$ & $1,415 a$ & $-124 b$ \\
\hline CR & 1,291 & $1,497 \mathrm{a}$ & $120 b$ & $1,377 \mathrm{a}$ & $-86 c$ \\
\hline \multirow[t]{2}{*}{ CB } & 1,291 & $928 b$ & $928 a$ & $\mathrm{Ob}$ & $1291 \mathrm{a}$ \\
\hline & \multicolumn{5}{|c|}{ Non-fertilized } \\
\hline $\mathrm{CC}$ & - & $368 a$ & $18 b$ & $350 a$ & $-350 a$ \\
\hline CR & - & $345 a$ & $21 b$ & $324 a$ & $-324 a$ \\
\hline $\mathrm{CB}$ & - & $297 b$ & $297 a$ & $\mathrm{Ob}$ & $\mathrm{Ob}$ \\
\hline
\end{tabular}

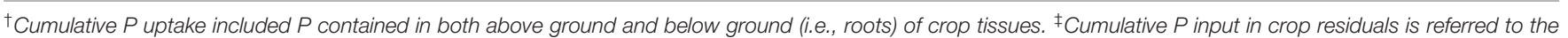

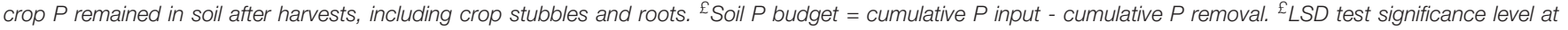
$P \leq 0.05$. CC, continuous corn; $C B$, continuous bluegrass sod; $C R$, corn-oats-alfalfa-alfalfa rotation.

Schoenau et al., 1989). The $\mathrm{HCl}$ solution extracts the relatively insoluble apatite-type materials, and $\mathrm{HCl}-\mathrm{P}$ may show the magnitude of soil weathering. Guo et al. (2000) found higher HCl-P in slightly weathered soil than highly weathered soil. The content of $\mathrm{HCl}-\mathrm{P}$ in our native Brookston clay loam was much lower than the low weathered Humic Cryaquept in Quebec in which the phyllosilicate mineralogy of clay fraction is dominated by vermiculite, hydrous mica, and feldspars (Zheng et al., 2003).

Continuous cropping without $\mathrm{P}$ fertilization significantly decreased total soil $\mathrm{P}$ content relative to the native soil after 45-2 cropping practices, ranging from an $18 \%$ to $30 \%$ decrease or 122 to $202 \mathrm{mg} \mathrm{P} \mathrm{kg}^{-1}$ soil (Figure 1). The result was coincident with studies reported by Crews and Brookes (2014) that significant soil P depletion occurred over time from 1893 to 2009 with Park Grass perennial hay meadow, by Hedley et al. (1982) that total $P$ in soils after 60 to 70 years cultivation was lower than that of adjacent permanent pasture, and by Bowman et al. (1990) that large declines of P (41\%) occurred after 60 years of cultivation. The sequence of total $\mathrm{P}$ reduction among our cropping systems followed the following order: $\mathrm{CC}>\mathrm{CR}>\mathrm{CB}$. The reduction of total $\mathrm{P}$ by cultivation was mainly due to $\mathrm{P}$ removal by plant (Hedley et al., 1982; Schoenau et al., 1989). Leaving the grass in place (i.e., the grass was consistently cut but not removed) in $\mathrm{CB}$ compared to crop removal in CC or CR plots would have reduced the total P loss from soils (Table 1). These results are consistent to the previous study that showed the larger $P$ accumulation in grass field was mainly due to more roots of perennial species compared to annual crops (Zheng et al., 2003). In addition, total P reduction in the cultivated plots relative to the native soil would have also been attributed to soil $\mathrm{P}$ losses in tile drainage. An annual P loss of $1.5 \mathrm{~kg} \mathrm{P} \mathrm{ha}^{-1}$ was observed in tile drainage water (Zhang et al., 2015), which contributes to greater than $70 \%$ of soil $P$ loss in the study region (Tan and Zhang, 2011; Zhang et al., 2013).

Application of fertilizer $\mathrm{P}$ resulted in a comparable total $\mathrm{P}$ in CC and CR plots, but significantly increased total P by $31 \%$ in $\mathrm{CB}$ relative to native soil (Figure 1). This was in agreement with the calculated $\mathrm{P}$ budget (Table 1 ). The $\mathrm{P}$ accumulation in soil with long-term application of fertilizer $\mathrm{P}$ has been reported by Mckenzie et al. (1992), Zhang et al. (1995), and Hao et al. (2018). The continuous application of fertilizer P, coupled with

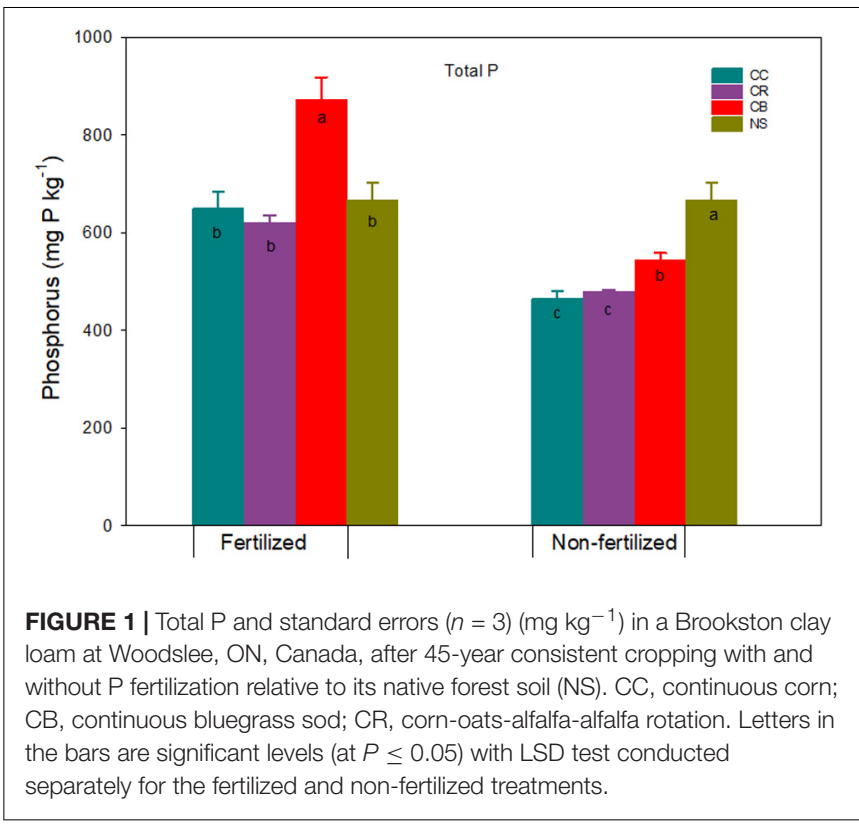

no crop removal in the $\mathrm{CB}$ plots, contributed to the increase of total P (Table 1 and Figure 1). The large increase in total P of grassland soils may increase the risk of P loss in runoff, leaching, and preferential flow (Zhang et al., 2015, 2017).

\section{Inorganic $\mathbf{P}$}

Consistent cropping without $\mathrm{P}$ fertilization significantly decreased all fractions of $\mathrm{P}_{\mathrm{i}}$, compared with native soil, by an average of $6,24,31$, and $21 \mathrm{mg} \mathrm{P} \mathrm{kg}{ }^{-1}$ for water- $\mathrm{P}_{\mathrm{i}}, \mathrm{NaHCO}_{3}-\mathrm{P}_{\mathrm{i}}$, $\mathrm{NaOH}-\mathrm{P}_{\mathrm{i}}$, and $\mathrm{HCl}-\mathrm{P}$, respectively (Figure 2 ). This resulted in a decrease in total extractable $\mathrm{P}_{\mathrm{i}}$ by an average of $82 \mathrm{mg} \mathrm{P} \mathrm{kg}^{-1}$ relative to native soil (Figure 3). Labile $\mathrm{P}_{\mathrm{i}}$ (water- $\mathrm{P}_{\mathrm{i}}+\mathrm{NaHCO}_{3}$ $\mathrm{P}_{\mathrm{i}}$ ) significantly decreased by 57 to $67 \%$ relative to native soil, which was greater than the $45 \%$ decrease reported by Hedley et al. (1982) for a soil after 65 years of cultivation. This decline was attributed to plant uptake of readily available $\mathrm{P}$ in the top layers of soil, as evidenced by the larger $\mathrm{P}$ removal relative to $\mathrm{P}$ input in crop residues including root and stubble biomass 
(Table 1). Although $\mathrm{NaOH}-\mathrm{P}_{\mathrm{i}}$ and $\mathrm{HCl}-\mathrm{P}$ in the non-fertilizer plots remained unchanged over a 5-year period (Zhang and MacKenzie, 1997a), this study showed a significant reduction in the two $\mathrm{P}$ pools in soil after 45-year cropping (Figure 2), suggesting moderately labile Pi was desorbed and the moderately stable $\mathrm{P}_{\mathrm{i}}$ dissolved to replenish readily labile $\mathrm{P}_{\mathrm{i}}$ pool in long-term cultivated soils. This transformation was previously reported by Crews and Brookes (2014) and (Sheklabadi et al., 2015). Few recent studies further concluded that the decline in $\mathrm{HCl}-\mathrm{P}$ is caused by the conversion from $\mathrm{HCl}-\mathrm{P}$ to readily available $\mathrm{P}_{\mathrm{i}}$ (von Sperber et al., 2017; Tiecher et al., 2018).

The decrease in labile $\mathrm{NaHCO}_{3}-\mathrm{P}_{\mathrm{i}}$ and moderately labile $\mathrm{NaOH}-\mathrm{P}_{\mathrm{i}}$ in $\mathrm{CR}$ and $\mathrm{CB}$ plots without $\mathrm{P}$ fertilization was significantly larger than in CC plots (Figure 2). The larger decrease of both $\mathrm{P}$ pools in CR plots could be explained by more $\mathrm{P}$ export of crop removal and resultant $\mathrm{P}$ desorption. The mean yield over 45 years in non-fertilized CR plots $\left(3.84 \pm 0.21 \mathrm{t} \mathrm{ha}^{-1}\right.$ year $\left.^{-1}\right)$ was significantly greater than in CC plots $(1.24 \pm 0.09$ $\mathrm{t} \mathrm{ha}^{-1}$ year $\left.^{-1}\right)$. This suggests that there was more available-P removal by crops in the $\mathrm{CR}$ treatment (Table 1), resulting in transformation of moderately labile $\mathrm{P}_{\mathrm{i}}$ to replenish the lower labile $\mathrm{P}_{\mathrm{i}}$. The readily available $\mathrm{P}$ appeared to be in equilibrium with moderately labile NaOH-P (Guo et al., 2000; Zhang et al., 2004). The larger decrease in both $P$ fractions in CB plots than in CC plots could be attributed to the stronger immobilization of $\mathrm{P}_{\mathrm{i}}$ to $\mathrm{P}_{\mathrm{O}}$, as was evidenced by the $\mathrm{CB}$ treatment having the highest content of $\mathrm{P}_{\mathrm{O}}$ among the three cropping systems (Figure 5). The immobilization of $\mathrm{P}_{i}$ to $\mathrm{P}_{\mathrm{o}}$ in grassland soil was reported previously by Herlihy and McGrath (2007) and Saltali et al. (2007). The HCl-P pool among the three cropping systems was not significantly different (Figure 2).

In $\mathrm{P}$ fertilized treatments, the concentrations of all $\mathrm{P}_{\mathrm{i}}$ fractions increased except for water- $\mathrm{P}_{\mathrm{i}}$ in the $\mathrm{CC}$ and $\mathrm{CR}$ plots and $\mathrm{HCl}$ $\mathrm{P}$ in the $\mathrm{CR}$ plots, compared to the native soil (Figure 2). The increases of $\mathrm{P}_{\mathrm{i}}$ were, on average, 13, 50, 65, and $34 \mathrm{mg} \mathrm{P} \mathrm{kg}^{-1}$ for water- $\mathrm{P}_{\mathrm{i}}, \mathrm{NaHCO}_{3}-\mathrm{P}_{\mathrm{i}}, \mathrm{NaOH}-\mathrm{P}_{\mathrm{i}}$, and $\mathrm{HCl}-\mathrm{P}$, respectively, and the resultant total extractable $\mathrm{P}_{\mathrm{i}}$ significantly increased with added fertilizer $\mathrm{P}$, ranging from 63 to $237 \mathrm{mg} \mathrm{P} \mathrm{kg}^{-1}$, as compared to the adjacent native forest soil (Figure 3 ). The addition of fertilizer P significantly elevated, as expected, the concentration of labile $\mathrm{P}_{\mathrm{i}}$ fractions (Wagar et al., 1986; Mckenzie et al., 1992; Zhang and MacKenzie, 1997a). The observations from this study indicated that the addition of fertilizer $\mathrm{P}$ encouraged the formation of $\mathrm{NaOH}-\mathrm{P}_{\mathrm{i}}$, reinforcing the conjecture that the $\mathrm{NaOH}-\mathrm{P}_{\mathrm{i}}$ acted as a sink of added $\mathrm{P}_{\mathrm{i}}$ under long-term fertilization (Zhang and MacKenzie, 1997b; Zheng et al., 2002; Zhang et al., 2004). Conversely, $\mathrm{NaOH}-\mathrm{P}_{\mathrm{i}}$ acted as a buffer for the available $\mathrm{P}$ in the non-fertilized soils (Zhang and MacKenzie, 1997a; Guo et al., 2000) or in soils that are running low in bioavailable $\mathrm{P}$ supply (Zhang et al., 2004). Clearly, the long-term response of $\mathrm{P}$ pools was controlled mainly by the dynamics of $\mathrm{NaOH}-\mathrm{P}_{\mathrm{i}}$ (von Sperber et al., 2017).

The increase in total extractable $\mathrm{P}_{\mathrm{i}}$ among cropping systems followed the sequence $\mathrm{CB}>\mathrm{CC}>\mathrm{CR}$ with increases of 237 , 173 , and $63 \mathrm{mg} \mathrm{P} \mathrm{kg}^{-1}$, respectively (Figure 3). The lower total extractable $\mathrm{P}_{\mathrm{i}}$ in the fertilized $\mathrm{CC}$ and $\mathrm{CR}$ plots than in the fertilized $\mathrm{CB}$ plots was attributed to the higher biomass yields and the greater removal of available $\mathrm{P}$ from soil (Table 1), whereas there was no $\mathrm{P}$ removal in the CB plots as they were not harvested. A small increase in total labile $\mathrm{P}_{\mathrm{i}}$ (Figure 3 ) and moderately labile $\mathrm{P}_{\mathrm{i}}$ (Figure 2) in CR did not yet result in the concurrent increase of $\mathrm{HCl}-\mathrm{P}$ (Figure 2), suggesting the transformation from labile and moderately labile $\mathrm{P}_{\mathrm{i}}$ pools to relative stable $\mathrm{P}$ pool was restricted in the rotation system. However, the concurrent increases of labile $\mathrm{P}_{\mathrm{i}}, \mathrm{NaOH}-\mathrm{P}_{\mathrm{i}}$, and $\mathrm{HCl}-\mathrm{P}$ in $\mathrm{CB}$ and $\mathrm{CC}$ plots relative to native forest soil indicated the greater transformation from labile and moderately labile $\mathrm{P}_{\mathrm{i}}$ to $\mathrm{HCl}-\mathrm{P}$ in these two treatments. This observation confirms the conclusion that $\mathrm{P}$ is transformed from readily available $\mathrm{P}$ forms to more resistant forms with the consecutive $\mathrm{P}$ fertilizer addition in monoculture systems (Zheng et al., 2002). Water- $P_{i}$ and the resultant total water-P in CB plots were 44 and $46 \mathrm{mg} \mathrm{P} \mathrm{kg}^{-1}$, which were significantly greater than in the other plots. It was speculated that the increase in water$\mathrm{P}$, especially water- $\mathrm{P}_{\mathrm{i}}$, might have resulted from the increase in the degree of soil $\mathrm{P}$ saturation, as evidenced by the increase in $\mathrm{NaHCO}_{3}-\mathrm{P}_{\mathrm{i}}$, a form of $\mathrm{P}$ that is predominately sorbed physically or physicochemically on the soil surface. Water-extractable P has been deemed a soil test indicative of environmental risk of soil P loss (Wang et al., 2010, 2012). Recent studies have found that concentrations of dissolved, bioavailable, and particulate $\mathrm{P}$ in runoff increased linearly as water-extractable $\mathrm{P}$ increases (Schroeder et al., 2004; Wang et al., 2010, 2012). The high water$\mathrm{P}_{\mathrm{i}}$ in $\mathrm{CB}$ plots could result in great potential $\mathrm{P}$ losses by runoff and leaching (Zhang et al., 2015).

\section{Organic P}

Consistent cropping without fertilization significantly decreased extractable $\mathrm{P}_{\mathrm{O}}$ fractions except for water- $\mathrm{P}_{\mathrm{O}}$, which was significantly increased compared to native soil (Figure 4). The $\mathrm{NaOH}-\mathrm{P}_{\mathrm{O}}$ and $\mathrm{NaHCO}_{3}-\mathrm{P}_{\mathrm{O}}$ decreased, on average, across the three cropping systems, by 58 and $15 \mathrm{mg} \mathrm{P} \mathrm{kg}^{-1}$, respectively. Although the proportion of increase was large, the increment of water- $\mathrm{P}_{\mathrm{o}}$ averaged approximately only $1.1 \mathrm{mg} \mathrm{kg}^{-1}$. Averaged across cropping systems, the decrease of $\mathrm{NaOH}-\mathrm{P}_{\mathrm{o}}$ accounted for $43 \%$ and $84 \%$ of total $\mathrm{P}$ and total extractable $\mathrm{P}_{\mathrm{o}}$ reductions, respectively (Figures 1, 5). This proportion of decrease was consistent with those reported by Hedley et al. (1982), 68\% of total $\mathrm{P}_{\mathrm{O}}$ loss after 65-years cultivation was attributed to the $\mathrm{NaOH}-\mathrm{P}_{\mathrm{o}}$ decrease. This was confirmed by the result from Zhang and MacKenzie (1997a), who found $\mathrm{NaOH}-\mathrm{P}_{\mathrm{o}}$ decreased by $46 \mathrm{~kg} \mathrm{P} \mathrm{ha}{ }^{-1}$ in the non-fertilized plots. These studies suggest that $\mathrm{NaOH}-\mathrm{P}_{\mathrm{o}}$ plays an important role as sink or source in $\mathrm{P}$ transformation in soils. For cropping systems, the sequence of total extractable $\mathrm{P}_{\mathrm{o}}$ decrease was $\mathrm{CC}>\mathrm{CR}>\mathrm{CB}$ (Figure 5). The $\mathrm{CC}$ and $\mathrm{CR}$ cropping practices decreased not only easily mineralized $\mathrm{P}_{\mathrm{O}}\left(\mathrm{NaHCO}_{3}-\mathrm{P}_{\mathrm{o}}\right)$, but also moderately labile $\mathrm{NaOH}-\mathrm{P}_{\mathrm{o}}$, especially for the portion of extractable $\mathrm{P}$ after $\mathrm{HCl}$ extraction (NaOH-2-P ) (Zhang and MacKenzie, 1997a). The greater decreases in $\mathrm{NaOH}-\mathrm{P}_{\mathrm{o}}$ in $\mathrm{CC}$ and $\mathrm{CR}$ plots than in $\mathrm{CB}$ plots, compared with native soil (Figure 5), indicate that the rate of $\mathrm{P}_{\mathrm{O}}$ mineralization was enhanced by agronomic practices such as tillage. Tiecher et al. (2018) assessed linkage between soil $\mathrm{P}$ forms in contrasting tillage systems using path analysis and concluded that the organic $\mathrm{P}$ pool has a greater direct 


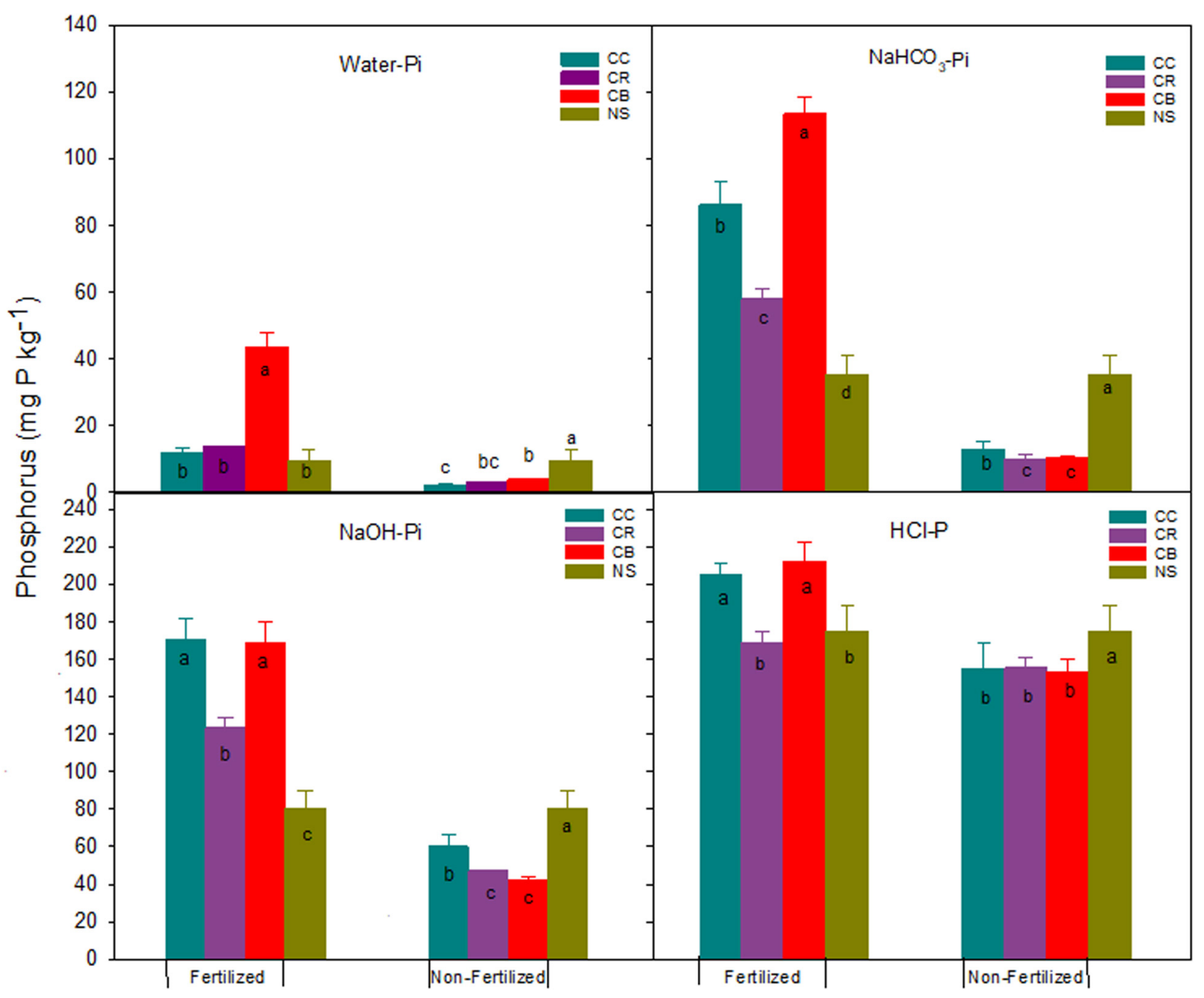

FIGURE 2 | Water- $\mathrm{P}_{\mathrm{i}}, \mathrm{NaHCO}_{3}-\mathrm{P}_{\mathrm{i}}, \mathrm{NaOH}-\mathrm{P}_{\mathrm{i}}, \mathrm{HCl}-\mathrm{P}$, and standard errors $(n=3)\left(\mathrm{mg} \mathrm{kg}^{-1}\right)$ in a Brookston clay loam at Woodslee, ON, Canada, after 45-year consistent cropping with and without $\mathrm{P}$ fertilization relative to its native forest soil (NS). CC, continuous corn; CB, continuous bluegrass sod; CR,

corn-oats-alfalfa-alfalfa rotation. Letters in or above the bars are significant levels (at $P \leq 0.05$ ) with LSD test conducted separately for the fertilized and non-fertilized treatments.

contribution to buffer resin-P under conventional tillage (94\%) than under non-tillage (35\%), due to higher mineralization of organic $\mathrm{P}$ forms with moderate lability caused by soil disturbance. A small decrease in total extractable $\mathrm{P}_{\mathrm{o}}$ in $\mathrm{CB}$ plots might have partially been due to the tradeoff of more $\mathrm{P}_{\mathrm{O}}$ being returned to soil in grass residues including shoots, as well as the massive roots (Table 1 and Figure 5).

In $\mathrm{P}$ fertilized plots, a significant decrease in all $\mathrm{P}_{\mathrm{o}}$ fractions was found in $\mathrm{CC}$ and $\mathrm{CR}$ plots, except for water- $\mathrm{P}_{\mathrm{O}}$ in $\mathrm{CC}$ and $\mathrm{NaHCO}_{3}-\mathrm{P}_{\mathrm{O}}$ in $\mathrm{CR}$ plots where they remained unchanged, relative to the native forest soil (Figure 4). This resulted in a significant decrease in the total extractable $\mathrm{P}_{\mathrm{O}}$ by 129 and $85 \mathrm{mg} \mathrm{P} \mathrm{kg}{ }^{-1}$ in CC and CR plots, respectively, as compared to the native soil (Figure 5). Res-P also decreased by 32 and $18 \mathrm{mg} \mathrm{kg}^{-1}$ in CC and CR plots (data not shown), respectively. Data obtained by Haas et al. (1961) for the soils from 15 dryland experiment stations in the US Great Plains showed that total $\mathrm{P}$ was reduced by an average of $8 \%$ by cropping over 30 to 48 years, with most of the loss being $\mathrm{P}_{\mathrm{o}}$. In contrast, with increases in $\mathrm{NaOH}-\mathrm{Po}$ (Figure 4), total extractable $\mathrm{P}_{\mathrm{o}}$ in $\mathrm{CB}$ plots increased by $10 \mathrm{mg} \mathrm{P} \mathrm{kg}^{-1}$ relative to native soil, although labile $\mathrm{P}_{\mathrm{o}}$, sum of water- $\mathrm{P}_{0}$ and $\mathrm{NaHCO}_{3}-\mathrm{P}_{0}$, decreased slightly by $8 \mathrm{mg} \mathrm{P} \mathrm{kg}^{-1}$ (Figure 5), due to the strong immobilization process in grassland (Herlihy and McGrath, 2007; Saltali et al., 2007).

In general, either soil labile $\mathrm{P}_{\mathrm{o}}$ or total extractable $\mathrm{P}_{\mathrm{o}}$ in the fertilized CC and CR treatments decreased, compared to the native soil (Figure 5). While the total labile $\mathrm{P}_{\mathrm{o}}$ decreased slightly, averaged at $8 \mathrm{mg} \mathrm{P} \mathrm{kg}^{-1}$ across three cropping systems, the predominant $\mathrm{P}_{\mathrm{o}}$ loss was observed in the form of $\mathrm{NaOH}-\mathrm{P}_{\mathrm{o}}$, with an average of $60 \mathrm{mg} \mathrm{kg}^{-1}$ across CC and CR. This confirms the previous observations reported by Zhang and MacKenzie (1997a). Tran and N'dayegamiye (1995) suggested the decrease of $\mathrm{NaOH}-\mathrm{P}_{\mathrm{o}}$ in $\mathrm{P}$ fertilized treatments was probably due to the 


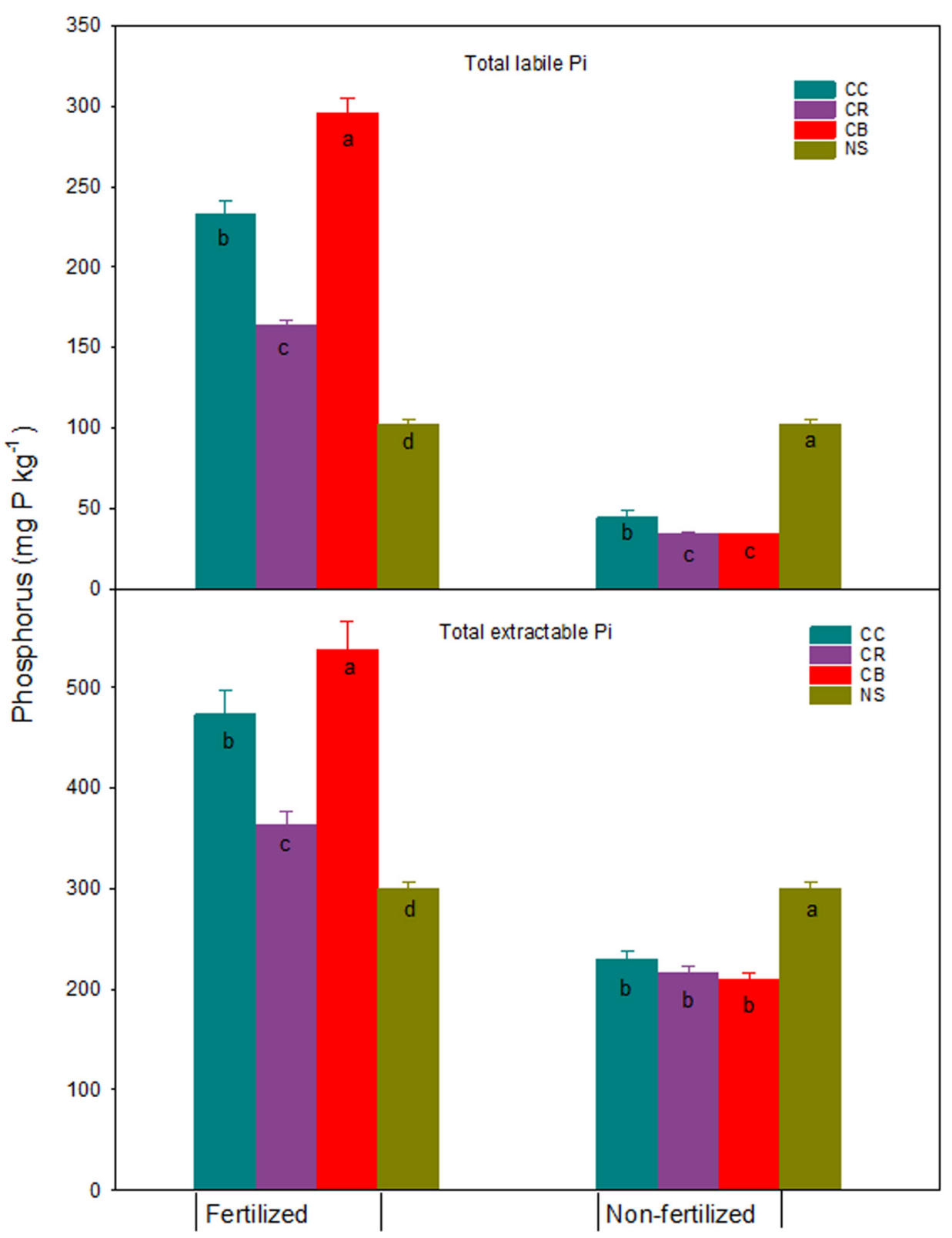

FIGURE 3 | Total extractable $\mathrm{P}_{\mathrm{i}}$ and labile $\mathrm{P}_{\mathrm{i}}$ and standard errors $(n=3)\left(\mathrm{mg} \mathrm{kg}^{-1}\right)$ in a Brookston clay loam at Woodslee, ON, Canada, after $45-\mathrm{year}$ consistent cropping with and without $\mathrm{P}$ fertilization relative to its native forest soil (NS). CC, continuous corn; CB, continuous bluegrass sod; CR, corn-oats-alfalfa-alfalfa rotation. Letters in the bars are significant levels (at $P \leq 0.05$ ) with LSD test conducted separately for the fertilized and non-fertilized treatments.

synergetic effect of $\mathrm{N}$ and $\mathrm{P}$ on soil $\mathrm{P}_{\mathrm{o}}$ mineralization. Significant decreases in total extractable $\mathrm{P}_{\mathrm{o}}$ in the fertilized CC and CR plots imply that fertilizer application alone cannot remedy $\mathrm{P}_{\mathrm{o}}$ loss by cropping practices, apart from returning more plant residues.

\section{CONCLUSION}

The significant decrease of total $\mathrm{P}$ and all $\mathrm{P}$ fractions by cropping practices was found in the non-fertilized soil relative to the native forest soil except for water-extractable $P_{0}$. The labile $P_{i}$ decrease accounted for the most proportion of total extractable $\mathrm{P}_{\mathrm{i}}$ decrease. The moderately labile $\mathrm{NaOH}-\mathrm{P}_{\mathrm{o}}$ was the dominant pool accounting for the loss of $\mathrm{P}_{\mathrm{o}}$ and total $\mathrm{P}$ in the non-fertilized soils. The addition of fertilizer $\mathrm{P}$ significantly increased all $\mathrm{P}_{\mathrm{i}}$ pools under the three cropping systems, except for water- $P_{i}$ with CC and $\mathrm{CR}$ and $\mathrm{HCl}-\mathrm{P}$ with $\mathrm{CR}$ where no changes were observed. The NaOH- $\mathrm{P}_{\mathrm{i}}$ largely increased after 45 years in the fertilized soils, whereas it decreased in the non-fertilized soils. This study revealed that long-term cropping practices significantly enhanced the rate of $P_{o}$ mineralization regardless of whether they were fertilized. Further, NaOH- $\mathrm{P}_{\mathrm{i}}$ and $-\mathrm{P}_{\mathrm{o}}$ played important roles by 


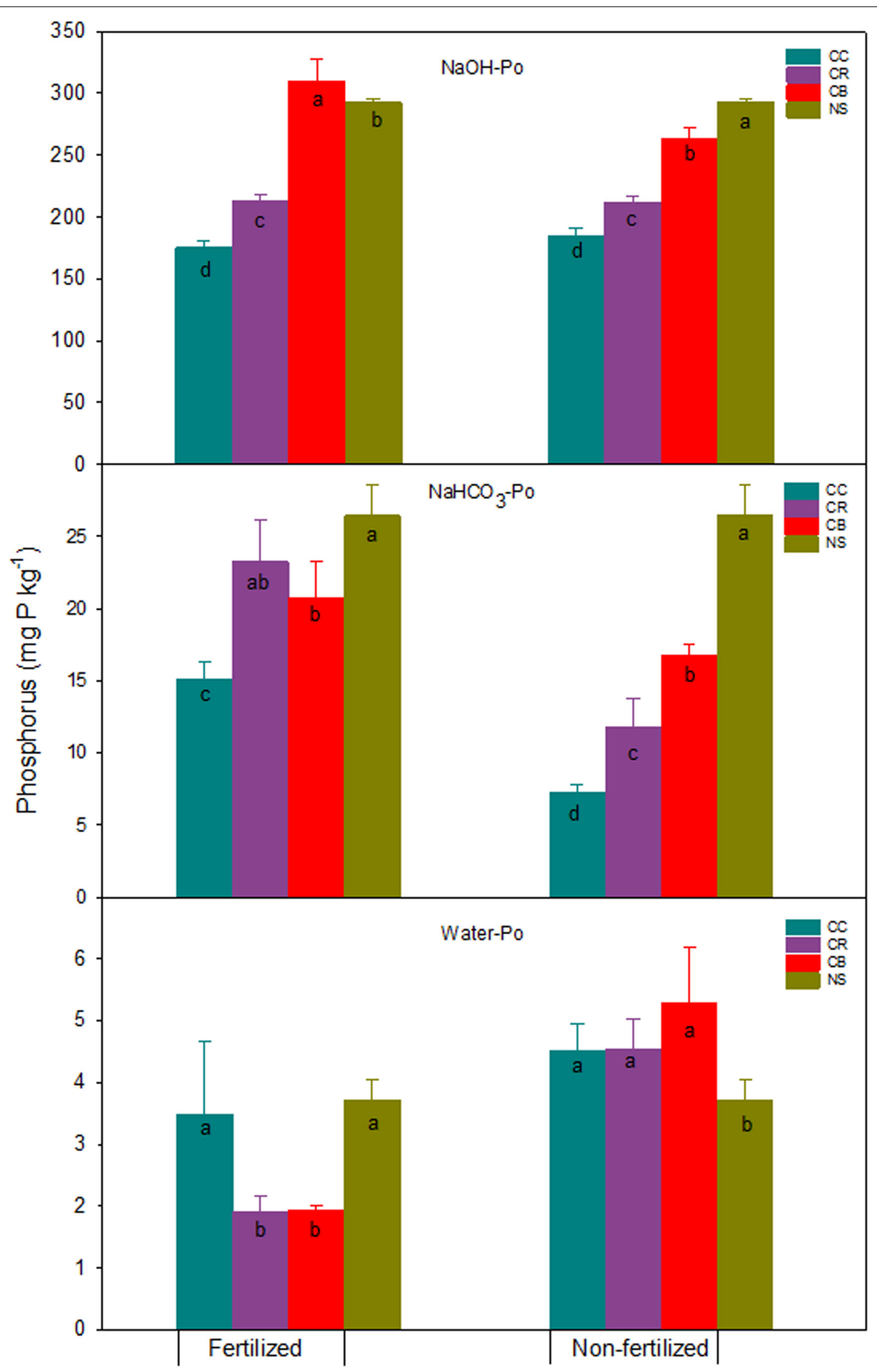

FIGURE 4 | Water- $\mathrm{P}_{\mathrm{O}}, \mathrm{NaHCO}_{3}-\mathrm{P}_{\mathrm{o}}, \mathrm{NaOH}-\mathrm{P}_{\mathrm{o}}$, and standard errors $(n=3)\left(\mathrm{mg} \mathrm{kg}^{-1}\right)$ in a Brookston clay loam at Woodslee, ON, Canada, after $45-y e a r$ consistent cropping with and without $P$ fertilization relative to its native forest soil (NS). CC, continuous corn; CB, continuous bluegrass sod; CR, corn-oats-alfalfa-alfalfa rotation. Letters in the bars are significant levels (at $P \leq 0.05$ ) with LSD test conducted separately for the fertilized and non-fertilized treatments. 


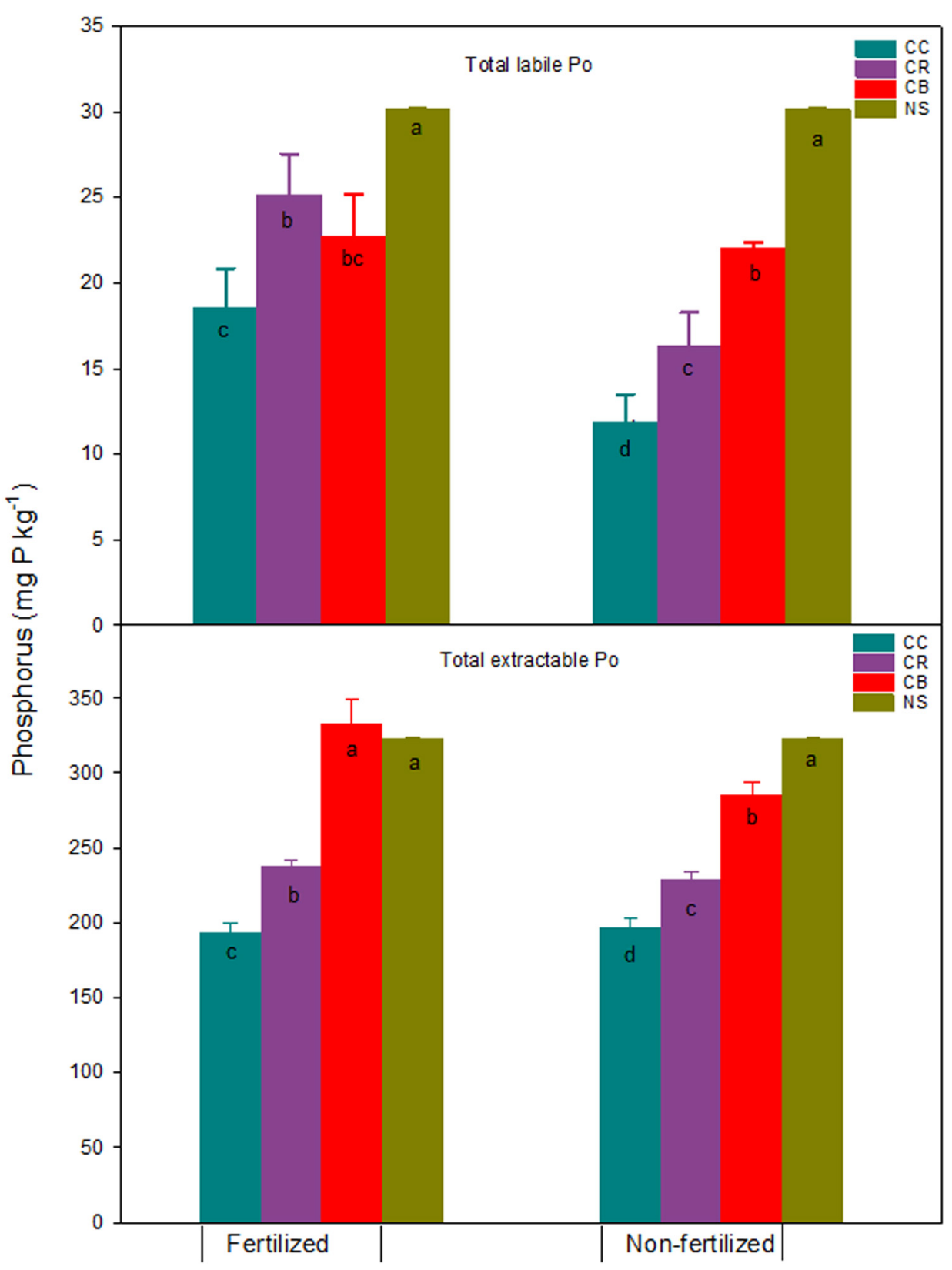

FIGURE 5 | Total extractable $\mathrm{P}_{\mathrm{O}}$ and labile $\mathrm{P}_{\mathrm{O}}$ and standard errors $(n=3)\left(\mathrm{mg} \mathrm{kg}^{-1}\right)$ in a Brookston clay loam at Woodslee, ON, Canada, after $45-y e a r$ consistent cropping with and without P fertilization relative to its native forest soil (NS). CC, continuous corn; CB, continuous bluegrass sod; CR, corn-oats-alfalfa-alfalfa rotation. Letters in the bars are significant levels (at $P \leq 0.05$ ) with LSD test conducted separately for the fertilized and non-fertilized treatments.

acting as a sink or source of $\mathrm{P}$ in this soil. The return of grass residues in the $\mathrm{CB}$ treatment resulted in the increases in total $\mathrm{P}$ and total $\mathrm{P}_{\mathrm{O}}$ in the fertilized plots relative to the native soil, suggesting $\mathrm{P}$ accumulation in grass fields is a concern as a risk of $\mathrm{P}$ pollution to adjacent fresh waters.

\section{DATA AVAILABILITY STATEMENT}

All datasets generated for this study are available upon request.

\section{AUTHOR CONTRIBUTIONS}

TZ proposed and facilitated the study. CD and few previous scientists in Harrow Research and Development Center (formerly Harrow Research Center or Greenhouse and Processing Crops Research Center), AAFC, maintained the long-term plots and provided the yield data. TZ, ZZ, QH, $\mathrm{CD}$, and CT contributed to the preparation of the manuscript. All authors contributed to the manuscript and approved the submitted version. 


\section{FUNDING}

Funding for this study was provided by the Agriculture and Agri-Food Canada A-base Research Program.

\section{REFERENCES}

Agbenin, J. O., and Goladi, J. T. (1998). Dynamics of phosphorus fractions in a savanna Alfisol under continuos cultivation. Soil Use Manage. 14, 59-64. doi: 10.1111/j.1475-2743.1998.tb00614.x

Ahmed, W., Jing, H., Kaillou, L., Qaswar, M., Khan, M. N., Jin, C., et al. (2019). Changes in phosphorus fractions associated with soil chemical properties under long-term organic and inorganic fertilization in paddy soils of southern China. PLoS One 14:e0216881. doi: 10.1371/journal.pone.0216881

Bolinder, M. A., Angers, D. A., Bélanger, G., Michaud, R., and Laverdière, M. R. (2002). Root biomass and shoot to root ratios of perennial forage crops in eastern Canada. Can. J. Plant Sci. 82, 731-737. doi: 10.4141/p01-139

Bolinder, M. A., Angers, D. A., and Dubuc, J. P. (1997). Estimating shoot to root ratios and annual carbon inputs in soils for cereal crops. Agric. Ecosyst. Environ. 63, 61-66. doi: 10.1016/s0167-8809(96)01121-8

Bolinder, M. A., Janzen, H. H., Gregorich, E. G., Angers, D. A., and Bygaart, A. J. V. (2007). An approach for estimating net primary productivity and annual carbon inputs to soil for common agricultural crops in Canada. Agric. Ecosyst. Environ. 118, 29-42. doi: 10.1016/j.agee.2006.05.013

Bowman, R. A., and Halvorson, A. D. (1997). Crop rotation and tillage effects on phosphorus distribution in the central Great Plains. Soil Sci. Soc. Am. J. 61, 1418-1422. doi: 10.2136/sssaj1997.03615995006100050020x

Bowman, R. A., Reeder, J. D., and Lober, R. W. (1990). Changes in soil properties in a central plains rangeland soil after 3,20, and 60 years of cultivation. Soil Sci. 150, 851-857. doi: 10.1097/00010694-199012000-00004

Cole, C. V., Innis, G. I., and Stewart, J. W. B. (1977). Simulation of phosphorus cycling in semiarid grasslands. Ecology 59, 1-15. doi: 10.2307/1935104

Crews, T. E., and Brookes, P. C. (2014). Changes in soil phosphorus forms through time in perennial versus annual agroecosystems. Agri. Ecosys. Environ. 184, 168-181. doi: 10.1016/j.agee.2013.11.022

Guo, F., Yost, R. S., Hue, A. V., Evensen, C. I., and Silva, J. A. (2000). Changes in phosphorus fractions in soils under intensive plant growth. Soil Sci. Soc. Am. J. $41,81-89$.

Haas, H. J., Grunes, D. L., and Reichman, G. A. (1961). Phosphorus changes in Great Plains soil as influenced by cropping and manure applications. Soil Sci. Soc. Amer. Proc. 15, 215-218.

Hao, X. J., Zhang, T. Q., Wang, Y. T., Tan, C. S., Qi, Z. M., et al. (2018). Soil test phosphorus and phosphorus availability of swine manures with long-term application. Agronomy. J. 110, 1943-1950. doi: 10.2134/agronj2017.07.0412

Hedley, M. J., Stewart, W. B., and Chauhan, B. S. (1982). Changes in inorganic and organic soil phosphorus fractions induced by cultivation practices and by laboratory incubation. Soil Sci. Soc. Am. J. 46, 970-976. doi: 10.2136/sssaj1982. $03615995004600050017 x$

Herlihy, M., and McGrath, D. (2007). Phosphorus fractions and adsorption characteristics in grassland soils of varied soil phosphorus status. Nutri. Cycling Agroecosyst. 77, 15-21.

Mckenzie, R. H., Stewart, J. W. B., Dormaar, J. F., and Schaaljie, J. B. (1992). Longterm crop rotation and fertilizer effects on phosphorus transformation. I. In a Chernozemic Soil. Can. J. Soil Sci. 72, 569-579. doi: 10.4141/cjss92-047

Murphy, J., and Riley, J. P. (1962). A modified single solution method for the determination of phosphorus in natural waters. Anal. Chem. Acta 27, 31-36. doi: 10.1016/s0003-2670(00)88444-5

National Research Council (1982). United States-Canadian Tables of Feed Composition: Nutritional Data for United States and Canadian Feeds. Washington, D.C: National Academy of Sciences, 156.

Richards, J. E., Bates, T. E., and Sheppard, S. C. (1995). Changes in the forms and distribution of soil phosphorus due to long-term corn production. Can J. Soil. Sci. 75, 311-318. doi: 10.4141/cjss95-045

Saltali, K., Kenan, K., and Rasim, K. (2007). Changes in Sequentially extractable phosphorus fractions in adjacent arable and grassland ecosystems. Arid Land Res. Manag. 21, 81-89. doi: 10.1080/15324980601074602

\section{ACKNOWLEDGMENTS}

We are most grateful to M. R. Reeb and B. Hohner for their expert technical assistance.

SAS Institute (1999). SAS user's guide. Statistics. Version 8, 2th Edn. Cary, NC: SAS Inst. Inc.

Schoenau, J. J., Stewart, J. W. B., and Bettany, J. R. (1989). Forms and cycling of phosphorus in prairie and boreal forest soils. Biogeochemistry 8, 223-237. doi: 10.1007/BF00002890

Schroeder, P. D., Radcliffs, D. E., Cabrera, M. L., and Belew, C. B. (2004). Relationship between soil test phosphorus and phosphorus in runoff: effects of soil series variability. J. Environ. Qual. 33, 1452-1463.

Sheklabadi, M., Mahboubi, A. A., Gharabaghi, B., and Ahrens, B. (2015). Longterm land-use change effects on phosphorus fractionation in Zrêbar Lake margin soils. Arch. Agron. Soil Sci. 61, 737-749. doi: 10.1080/03650340.2014. 954106

Simard, R. R., Cluis, D., Gangbazo, G., and Beauchemin, S. (1995). Phosphorus status of forest and agricultural soils from a watershed of high animal density. J. Environ. Qual. 24, 1010-1017. doi: 10.2134/jeq1995.0047242500240005 $0033 \mathrm{x}$

Takeda, M., Nakamoto, T., Miyazawa, K., and Murayama, T. (2009). Phosphorus transformation in a soybean-cropping system in Andosol: effects of winter cover cropping and compost application. Nutr. Cycling Agroecosyst. 85, 287297. doi: 10.1007/s10705-009-9267-6

Tan, C. S., and Zhang, T. Q. (2011). Surface runoff and sub-surface drainage phosphorus losses under regular free drainage and controlled drainage with sub-irrigation systems in southern Ontario. Can. J. Soil Sci. 91, 349-359. doi: $10.4141 /$ cjss09086

Tiecher, T., Gomes, M. V., Ambrosini, V. G., Amorim, M. B., and Bayer, C. (2018). Assessing linkage between soil phosphorus forms in contrasting tillage systems by path analysis. Soil Tillage Res. 175, 276-228.

Tiessen, H., and Moir, J. O. (1993). "Characterization of available P by sequential extraction," in Soil Sampling and Methods of Analysis, ed. M. R. Carter (Boca Raton, FL: Lewis Publishers), 75-86.

Tiessen, H., Stewart, J. W. B., and Bettany, J. R. (1982). The effect of longterm cultivation on the concentrations and total amounts of carbon, nitrogen, and organic and inorganic phosphorus in three grassing soils. Agron. J. 74, 831-835.

Tiessen, H., Stewart, J. W. B., and Moir, J. O. (1983). Changes in organic and inorganic phosphorus composition of two grassland soils and their particle size fractions during 60-90 years of cultivation. J. Soil Sci. 34, 815-823. doi: 10.1111/j.1365-2389.1983.tb01074.x

Tran, T. S., and N'dayegamiye, A. (1995). Long-term effects of fertilizers and manure application on the forms and availability of soil phosphorus. Can. J. Soil Sci. 75, 281-285. doi: 10.4141/cjss95-040

von Sperber, C., Stallforth, R., Du Preez, C., and Amelung, W. (2017). Changes in soil phosphorus pools during prolonged arable cropping in semiarid grasslands. Eur. J. Soil Sci. 68, 462-471. doi: 10.1111/ejss. 12433

Wagar, B. I., Stewart, J. W. B., and Moir, J. O. (1986). Changes with time in the form and availability of residual fertilizer phosphorus on Chernozemic soil. Can. J. Soil Sci. 66, 105-119. doi: 10.4141/cjss86-011

Wang, Y. T., Zhang, T. Q., Hu, Q. C., O’Halloran, I. P., Tan, C. S., and Reid, K. (2012). Soil tests as risk indicators for leaching of dissolved phosphorus from agricultural soils in Ontario. Soil Sci. Soc. Ame. J. 76, 220-229. doi: 10.2136/sssaj2011.0175

Wang, Y. T., Zhang, T. Q., Hu, Q. C., Tan, C. S., O’Halloran, I. P., Drury, C. F., et al. (2010). Estimating dissolved phosphorus concentration in surface runoff water from major Ontario soils. J. Environ. Qual. 39, 1771-1781. doi: 10.2134/ jeq2009.0504

Zhang, T. Q., and MacKenzie, A. F. (1997a). Changes of phosphorus fractions under continuous corn production in a temperate clay soil. Plant Soil 192, $133-139$.

Zhang, T. Q., and MacKenzie, A. F. (1997b). Changes of phosphorus fractions under long-term corn monoculture. Soil Sci. Soc. Am. J. 61, 485-493. 
Zhang, T. Q., MacKenzie, A. F., and Liang, B. C. (1995). Long-term Changes in Mehlich-3 extractable $\mathrm{P}$ and $\mathrm{K}$ in a sandy clay loam soil under continuous corn (Zea mays L.). Can. J. Soil Sci. 75, 361-367. doi: 10.4141/cjss95-052

Zhang, T. Q., MacKenzie, A. F., Liang, B. C., and Drury, C. F. (2004). Soil test phosphorus and phosphorus fractions with long-term phosphorus addition and depletion. Soil Sci. Soc. Am. J. 68, 519-528. doi: 10.2136/sssaj2004. 5190

Zhang, T. Q., Tan, C. S., Wang, Y. T., Ma, B. L., and Welacky, T. (2017). Soil phosphorus loss in tile drainage water from long-term conventional- and notillage soils with and without compost addition. Sci. Total Environ. 580, 9-16. doi: 10.1016/j.scitotenv.2016.12.019

Zhang, T. Q., Tan, C. S., Zheng, Z., and Drury, C. F. (2013). "Tile drainage phosphorus losses from agricultural soils: case studies in Canada," in Proceedings of the ASA-CSSA-SSSA International Annual Meeting Jointed with Canadian Society of Agronomy Meeting, Tampa, 3-6.

Zhang, T. Q., Tan, C. S., Zheng, Z. M., and Drury, C. F. (2015). Tile drainage phosphorus loss with long-term consisting cropping systems and fertilization. J. Environ. Qual. 44, 503-511. doi: 10.2134/jeq2014.04.0188

Zheng, Z., MacLeod, J. A., Lafond, J., Sanderson, J. B., and Campbell, A. J. (2003). Phosphorus status of a Humic Gleysol after 10 years of cultivation under contrasting cropping practices. Can. J. Soil Sci. 83, 537-545. doi: 10.4141/s 03-011

Zheng, Z., Simard, R. R., Lafond, J., and Parent, L. E. (2002). Pathways of soil phosphorus transformations after 8 years of cultivation under contrasting cropping practices. Soil Sci. Soc. Am. J. 66, 999-1007. doi: 10.2136/sssaj2002. 9990

Zheng, Z. M., and Zhang, T. Q. (2012). "Soil phosphorus tests and transformation analysis to predict plant availability: a review," in Soil Fertility, ed. J. Whaley (London: InTech - Open Access Publisher), 19-36.

Conflict of Interest: The authors declare that the research was conducted in the absence of any commercial or financial relationships that could be construed as a potential conflict of interest.

Copyright (c) 2020 Zhang, Zheng, Drury, Hu and Tan. This is an open-access article distributed under the terms of the Creative Commons Attribution License (CC BY). The use, distribution or reproduction in other forums is permitted, provided the original author(s) and the copyright owner(s) are credited and that the original publication in this journal is cited, in accordance with accepted academic practice. No use, distribution or reproduction is permitted which does not comply with these terms. 